\title{
Changes in Latitudes, Differences in Attitudes: Assessing the Distinctiveness of Southern State Legislators
}

\author{
Joel F. Turner \\ Scott Lasley \\ Western Kentucky University \\ joel.turner@wku.edu scottlasley@wku.edu jeffrey.kash@wku.edu
}

\begin{abstract}
A variety of studies examine how motivation affects the decisions made, and the activities engaged in, by politicians. One area that is frequently ignored is whether there are regional differences among state legislators as it relates to ambition and behavior. Utilizing data from a survey administered to state legislators from all 50 states, this research demonstrates that legislators from Southern states exhibit significantly higher levels of progressive ambition than those from non-Southern states, and that this increased level of ambition exerts a significant impact on the types of activities Southern legislators would prefer to spend their time engaging in.
\end{abstract}

\section{Introduction}

No region has drawn more interest in the study of American politics than the South. For years, political researchers worked under the assumption that the South was distinct when it came to politics, yet the explanation of how this regional identity shapes political behavior is not clear. While aggregate differences between Southern states and the rest of the nation are easy to identify, existing research routinely finds differences in the individual political behavior of Southerners as well. This research explores the linkages between regional identity and political behavior by investigating how Southern distinctiveness shapes the behaviors of state legislators. Specifically, it addresses how Southern legislators compare with their colleagues nationwide in terms of their interest in running for higher office and their allocation of time spent performing electoral and legislative responsibilities. Using responses from a survey of over 800 state legislators, the study finds that there are substantive differences between legislators from the South and those from other regions. Southern legislators are more likely to express progressive ambition; they spend and would like to spend more time on campaign activities; and they express an interest in spending less time performing legislative activities.

\section{Southern Distinctiveness}

Regional identity is featured prominently in literature focusing on the American South. From Cash's (1941) work on the "mind of the South", to Reed's (1982) examination of a shared regional identity among Southern whites, to Griffin's (2006) summary of the factors underpinning this collective identity, there is something about the South that makes it "distinct" as a region. Southerners are more likely to be conservative with regards to religious, moral, and racial issues (Glenn and Simmons 1967; Hurlbert 1989; Kuklinski, Cobb and Gilens 1997; Rice, McLean, and Larsen 2002). Demographically, the South has a higher minority population, and a lower collective education level, than other regions of the country (Cooper and Knotts, 2004). The key to explaining the role of Southern distinctiveness is to connect these broader regional characteristics to a set of values that impact political behavior. 
For the bulk of the century following the Civil War, Democrats essentially held a monopoly on elected offices in Southern states. This Democratic dominance led to disproportionate numbers of uncontested legislative elections (Squire 2000) and an overall lack of interparty competition in Southern states (Holbrook and Van Dunk 1993). Institutionally, party organizations have been relatively weak and underdeveloped (Gibson, et al. 1983). It is only over the past 50 years that two-party competition has emerged in Southern states. The emergence of Republican success, coupled with a fairly rapid population growth, has raised the perceived importance of the American South in national elections. Many Southern scholars have discussed the ability of Southern states to determine the winner of presidential elections (e.g. Black and Black 1992). Southern politicians have also grown in prominence and influence on the national political stage, particularly among congressional Republicans (Bullock 2009). While race has long played a central role in the politics of the South (Key 1949), the transformation of Southern politics generated scholarly interest into how and why the Republican Party was able to make significant and rapid gains, and what role race may have played in these political changes (e.g. Valentino and Sears 2005).

A general conclusion to draw from the existing literature on Southern politics is that the region exhibits distinctiveness in political behavior in a number of areas. These include voter turnout, rates of split-ticket voting, voter decision-making, ideological conservatism, party affiliation, level of interparty competition, and the composition of state legislatures (Burden and Kimball 2002; Wattenberg 2002; Cowden 2001; Johnston 2001; Hillygus and Shields 2008; Squire 2000; Holbrook and Van Dunk 1993; Gibson, et al. 1983; King 2000; Harmel and Hamm 1986; Hamm and Harmel 1993). These findings, combined with research analyzing the importance of Southern states in national elections, supports the notion that Southern legislators differ from their non-Southern counterparts (Black and Black 1992; Bullock 2009; Valentino and Sears 2005; Turner, Lasley and Kash Forthcoming). The next step is to explain how their Southern distinctiveness shapes their political behaviors.

The values defining Southern political distinctiveness are rooted in history and the evolution of a regional political culture. Political culture proves useful because it describes, at a collective level, phenomena that translates a region's history, economic, social, and political dynamics into a set of common values that help to explain behavior. Its strength also creates a weakness because the collective nature of the concepts makes creating clear causal connections between cultural values and observed political behaviors at the individual level difficult to test. Early research on Southern political culture by Elazar (1966) argues that Southern states fall into the category of a traditionalist political subculture. Traditionalists operate in a world where social connections and prestige matter, and politics centers on dominant personalities or families who attempt to control the system and perpetuate the status quo. Although Elazar's work provides support for the idea of a distinct Southern political culture and it broadly identifies a general set of values, it does not provide a causal mechanism for how Southern political culture shapes the behavior of Southern legislators.

Researchers studying Southern legislatures frequently control for the influence of political culture on legislative behavior (King 2000). There are cases where the institutional behavior of members of Southern legislatures differs from other legislative bodies. For example, 
party leadership has been historically weak in Southern legislatures (Harmel and Hamm 1986; Hamm and Harmel 1993). Southern influence on legislative professionalism also seems to be marginal (King 2000). The region does appear to influence the composition of state legislatures, as Southern states tend to have fewer female legislators, as well as a disproportionate number of lawyers, realtors, and insurance agents serving in institutions (Squire 1992). These common regional differences continue to appear when investigating voter turnout and voter registration laws, with Southern states incorporating more restrictive voter registration laws and lower rates of voter turnout (King 1994). These findings suggest that Southern distinctiveness plays a significant role in political behavior.

Policy studies of legislatures identify relationships between Southern political culture and public policies (Johnson 1976; Hero and Fitzpatrick 1988). Johnson (1976) found that Southern states generally had government programs that were smaller in scope and lower in cost. Morgan and Watson (1981) also found strong relationships between political culture, political processes, and policy outputs. Minimal support, however, was found for the direct influence of political culture on institutions outside of behavior. This suggests that the measurement of how common political values are translated into institutional design is difficult. It also suggests that similarity in institutional designs across states does not guarantee that the individuals operating the institutions and interpreting their rules do so in uniform ways. Comparative research on political institutions suggests that some institutions incorporate regional values into their design and operating procedures. These institutions frequently reward individuals that successfully conform to regional norms (Putnam 1993). Although the specific cultural values are not clearly identified, the findings from research addressing Southern distinctiveness suggest that Southern legislatures may reward behaviors that fit with cultural values. An explanation of Southern distinctiveness then should address why institutions and voters reward politicians that reinforce Southern political values.

Erikson, McIver, and Wright (1987) build a compelling case for the influence of political culture on partisanship and ideology. While they generally find that state political culture is more influential than regional culture, it is the uniformity of cultural distinctiveness across the South that inflates the influence of region as a variable. Outside the South, region has relatively modest impact on partisanship and ideology. The consistent impact of Southern distinctiveness may be connected to how political values were shaped by the common experiences of slavery, single party dominance, the civil rights movement, low educational rates, and the more recent rapid changes in population growth, and dramatically shifting party allegiances. No other region has had to adapt its political culture to these powerful social and political forces that occurred quite like the South.

Supporting the contention that clear causal theories are hard to find in cultural explanations, some studies of Southern politics question the ability of political cultures to explain outcomes. Hero and Tolbert (1996) argue that racial and ethnic diversity explain policy variations across states. Nardulli (1990) questions the applicability of Elazar's subcultures at the individual level. These questions about the applicability of political culture as an explanation of Southern distinctiveness identify one of the purposes of this research, which is to assess whether 
Southern distinctiveness provides a more useful explanation of political behavior than these demographic or individual level characteristics.

This review of the literatures addressing Southern distinctiveness supports two working assumptions that guide this research. First, it suggests the existence of a distinctive Southern political culture that is defined by a common political history as well as a common set of values. Second, it establishes a common set of political behaviors amongst Southern politicians and their constituents. Because state political cultures may be classified in part by the attitudes of their politicians (Erikson, McIver, and Wright 1987), it is reasonable to expect that Southern politicians will be different from those from other regions of the country.

As stated previously, the linkage between political culture and values is important for explaining the influence of Southern distinctiveness. The next link to be established in this causal chain is between values and behavior. Political scientists argue the legislators act strategically to meet their political goals. They prioritize behaviors that support their reelection (Mayhew, 1974). This need for reelection supports strategic behavior in institutional settings as well as when meeting with constituents. Fenno finds that members of Congress strategically adapt their behaviors to meet the needs of their constituents in their home districts. He calls this behavior "homestyle" (Fenno 2003). Using the idea of a common homestyle or set of strategic behaviors as a starting point, Southern regional identity captures a common set of political values amongst voters in the region. Responding to this regional identity, legislators may adopt a common set of political behaviors to meet their strategic goals.

The research on homestyle suggests that members of rural districts may prefer face-to-face interactions with their constituents in pursuit of electoral success (Fenno 2003). For much of its history, Southern voters have reflected a more rural set of values in terms of their strong religious beliefs, lower levels of education, lower voter turnout, and limited role for government. Recent growth in the influence of the Republican Party in the South appears to reinforce these rural values as a defining characteristic of Southern distinctiveness. This study assumes that Southern legislators choose political behaviors that reinforce their constituents' regional identity. It investigates Southern legislators' attitudes towards political ambition, legislative activity, and electoral activity.

Specifically, the research seeks to determine whether there are key differences between Southern state legislators and their non-Southern counterparts when it comes to three areas. First, we compare the progressive ambition of Southern versus non-Southern legislators. The other two areas of interest are closely related. The second area is whether region matters in the amount of time that legislators actually spend performing electoral and legislative activities. Finally, the third issue is whether regional variation exists in the amount of time that legislators would like to spend performing those same activities. Based on the importance of Southern regional identity in the literature, the research pursues the following hypotheses for Southern legislators. The expectation is that state legislators from the South will spend more time performing electoral activities. This is directly related to the assumption that they emphasize face-to-face interactions with their voters. Supporting this hypothesis, the analysis predicts Southern legislators will also want to spend more time on those activities. Conversely, the analysis predicts that Southern legislators will spend less time working on legislative activities 
than non-Southern colleagues and be less likely to want to spend time performing legislative activities. From a strategic perspective, legislative activity provides less benefit to Southern legislators because their constituents want more limited government. The next section provides a description of the literature addressing political ambition.

\section{Ambition}

Political behavior is shaped by a multitude of personal and contextual influences. Ambition is an individual-level characteristic that shapes the dynamics of one's political career. The idea that ambition drives political behavior is not a new one. It has long been assumed that a politician's behavior is a response to political goals. Schlesinger (1966) identified three categories of political ambition: progressive, static, and discrete. Politicians with progressive ambition are those that desire higher office, while the primary goal of politicians with static ambition is reelection to their current office. In an early study of Connecticut legislators, more ambitious lawmakers were more willing to label themselves as politicians, expressed a greater desire to make their living from politics, and were more active legislators (Barber 1965). Another early study found that Michigan legislators modified their decision making as a response to their political ambitions (Soule 1969). Since these early studies, additional efforts have been made to understand political ambition and ultimately untangle the relationship between political ambition and legislative behavior.

Like many concepts in political science, political ambition is both a dependent and independent variable. Not only is it important to understand how ambition influences political behavior, but there is great value in understanding sources of variation in the levels of political ambition across politicians in the first place. Previous research has demonstrated that progressive ambition influences career behavior and should be considered when studying lawmakers (Gaddie, 2003). However, most research in this area has disproportionately focused on the impact of ambition on political behavior than on factors that shape levels of ambition (Maestas, et al. 2006). This study treats progressive political ambition as both a dependent and independent variable. The first issue to explore is whether geography influences the degree of progressive ambition expressed by state legislators. Specifically, the research is focused on whether state legislators from Southern states are more likely to express interest in running for higher office than their non-Southern counterparts. Southern regional identity shapes legislators' attitudes toward seeking higher office in three ways. First, the conclusion that Southern voters support limited government suggests that legislative success is not a sound strategy for gaining their support. Second, working under the assumption that Southern voters respond to face-to-face interactions more readily than legislative contributions, the greater attention garnered by being elected into higher office is a reasonable strategy for Southern legislators. Finally, the South's history of one-party rule defined by a powerful social elite as well as its more recent importance in determining national electoral outcomes makes seeking higher office a sound political strategy.

The above reasoning suggests that theoretically the study should find higher levels of motivation for pursuing higher office in Southern legislators. The corollary to this is that legislators from outside of the South may be less interested in the pursuit higher office because 
their voters do not share a common set of values with Southern voters. The findings presented here suggest that when controlling for other influences, Southern legislators express greater interest in running for higher office. The analysis also uses ambition as an independent variable in the later models. This provides the opportunity to explore if Southern legislators allocate time differently even when controlling for levels of progressive ambition.

\section{Data and Methods}

Data for the present study were obtained from a September 2010 survey of legislators in all 50 U.S. states. ${ }^{1}$ A total of 7,199 state legislators were contacted, of which 867 participated, giving us a response rate of roughly $12 \% .^{2} 157$ of the respondents, or $18 \%$ of the sample, were from Southern states. Politically speaking, our sample is just slightly Democratic (51\%) and 48\% selfidentify as at least somewhat conservative. Demographically, $68 \%$ of our respondents were male, and $91 \%$ were white. 3 The primary substantive focus of the survey was legislator attitudes toward legislative professionalization. Additional questions addressed matters such as partisanship, ideology, length of legislative service, and attitudes toward aspects of legislative behavior.

Five dependent variables are used in this analysis. The first is a measure of the legislator's level of political ambition. In the survey we asked legislators how interested they would be in running for higher office in the future. Responses were coded as 0 if the respondent has no interest in running for higher office, 1 if the respondent would not rule out pursuing higher office but is not currently interested, 2 if the respondent might run for higher office, and 3 if the respondent is definitely interested in running for higher office.

The second dependent variable measures how much time state legislators spend engaging in campaign activities. The survey asked legislators how much time they spend engaging in the following activities: meeting with citizens in the district, meeting with constituents in the capital, fundraising, and giving speeches outside of the district. Response options were zero (almost none), one (a little), two (a moderate amount), and three (a great deal). The four were then added to create a summary campaign activities measure, which ranged from a low of zero to a high of twelve.

The third dependent variable measures how much time state legislators spend engaging in legislative activities. The survey asked legislators how much time they spend engaging in the following activities: attending committee meetings, meeting in the capital on legislative issues, studying pending legislation, attending floor debate, working with party leaders to build

\footnotetext{
1 This study was performed with the approval of, and within the guidelines of, the Western Kentucky University Institutional Review Board.

2186 of the legislators we attempted to contact had email addresses that were not functional. 140 legislators opted out of receiving emails about the survey after the first attempt to contact them. In addition, we were notified that a couple of the legislators we attempted to contact were deceased.

3 In our sample, female and minority legislators were slightly overrepresented (32\% of sample versus $25 \%$ of actual legislators), and Southern legislators were slightly underrepresented ( $18 \%$ of sample versus $25 \%$ of actual legislators). Weighting of the data to account for this did not result in any meaningful change to the results, so the unweighted data is reported.
} 
coalitions, conducting agency oversight. Response options were zero (almost none), one (a little), two (a moderate amount), and three (a great deal). The six were then added to create a summary legislative activities measure, which ranged from a low of zero to a high of fourteen.

The fourth dependent variable measures how much time state legislators would ideally like to spend engaging in campaign activities. The key difference between this variable and the second variable is that this is a measure of how much time legislators would prefer to engage in campaign activities as opposed to the actual time spent. Legislators were asked how much time they would like to spend engaging in the following activities: meeting with citizens in the district, meeting with constituents in the capital, fundraising, and giving speeches outside of the district. Response options were zero (almost none), one (a little), two (a moderate amount), and three (a great deal). The four were then added to create a summary ideal campaign activities measure, which ranged from a low of zero to a high of eleven.

The fifth dependent variable measures how much time state legislators would ideally spend engaging in legislative activities. Legislators were asked how much time they would ideally like to spend engaging in the following activities: attending committee meetings, meeting in the capital on legislative issues, studying pending legislation, attending floor debate, working with party leaders to build coalitions, conducting agency oversight. Response options were zero (almost none), one (a little), two (a moderate amount), and three (a great deal). The six were then added to create a summary ideal legislative activities measure, which ranged from a low of zero to a high of thirteen.

A Cronbach's alpha test indicated that it was proper to scale these dependent variables to create index measures. However, this made analysis less straightforward, as a simple regression would not yield results that could be interpreted in a meaningful manner while some type of count analysis would prove problematic due to the variety of different potential cut points across the variables in question. Therefore, the dependent variables regarding time spent campaigning and legislating, as well as the ideal amount of time spent campaigning and legislating, were collapsed into three categories, representing a little amount, a moderate amount, and a great deal of time spent engaging in each. This approach will allow us to conduct an ordered logit analysis as well as produce substantively interesting predicted probabilities.

Eleven independent variables are used in this analysis. The first, Southern, measures whether the responding legislator is from a Southern state. This variable is coded zero if the respondent is not from a Southern state and one if the respondent is from a Southern state. ${ }^{4}$ The second independent variable measures the level of professionalization in each state legislature. This measure is taken from Squire's (2007) work on state legislatures. The third independent variable, developed by Beyle (2007) is a measure of gubernatorial power in the state. The fourth independent variable, sex, is coded 0 if the respondent was male and 1 if the respondent was female. The fifth dependent variable, term limits, is coded 0 for states without term limits and 1 for states that have term limits. Also, a control for how close in size the districts these legislators represent were to the size of a U.S. congressional district was used to account for both the

\footnotetext{
${ }^{4}$ Determination over what constitutes a Southern state was made by inclusion in Bullock and Rozell's (2009) seminal work New Politics of the Old South. These states include Alabama, Arkansas, Florida, Georgia, Louisiana, Mississippi, North Carolina, Oklahoma, South Carolina, Tennessee, Texas, and Virginia.
} 
likelihood of winning the district but also for the possibility that legislators representing larger districts may be more comfortable with the idea of potentially being a member of Congress, which might influence their level of progressive ambition. For instance, a state house member from New Hampshire represents an average of roughly 3300 people, whereas a state senator from California represents over 930,000 people. This variable was calculated by dividing the size of the district the legislator represents by the size of a U.S. Congressional district.

Party identification is coded 0 if the respondent is a Democrat and 1 if the respondent is a Republican. Leadership measures whether a legislator holds a leadership position in their state's legislature. This is coded zero if the legislator does not hold a leadership position and one if the legislator does hold a leadership position. The tenure variable measures how long the respondent has been in office. It is coded 0 if the legislator has served two years or fewer, 1 if the respondent has served between three and six years, 2 if the respondent has served between seven and ten years, and 3 if the respondent has been in office longer than ten years. Race is coded zero if the respondent is white and one if the respondent is non-white. The political ambition variable used as a dependent variable in the first model will also be used as an independent variable in models two and three. 


\section{Results}

The model in Table 1 illustrates which characteristics of legislators influence legislative ambition. Because the dependent variable is categorical, an ordered logit model was estimated. The positive coefficient operating on the Southern variable indicates that Southern legislators are more likely to exhibit a higher level of political ambition than nonSouthern legislators. The coefficient for gubernatorial power is also positive and significant, which indicates that legislators in states with stronger governors exhibit higher levels of political ambition than states with weaker governors. Tenure and sex have negative coefficients, which indicate that those who are relatively new to the office and female legislators exhibit lower levels of ambition than men or those who have served longer terms in their current office. Legislative professionalization, whether a legislator holds a leadership position, race, district size, party identification, and the existence of term limits in a state failed to reach statistical significance.

Although logit coefficients are informative in regards to the direction of, and the statistical significance of, the effect of independent variables, they are difficult to interpret and provide little information regarding substantive impact. Therefore, predicted probabilities were calculated in order to highlight the effect of being a Southern legislator, sex, length of tenure, and gubernatorial power on legislative ambition.

Table 1: Ambition to Pursue Higher Office by Legislator Characteristics*

\begin{tabular}{|c|c|}
\hline Southern & $1.134(.204)^{* * *}$ \\
\hline Leadership & $.444(.428)$ \\
\hline Professionalization & $.602(1.01)$ \\
\hline Gubernatorial Power & $.662(.194)^{* * *}$ \\
\hline Democrat/Republican & $.067(.151)$ \\
\hline Tenure & $-.264(.075)^{* * *}$ \\
\hline Female & $-.389(.158)^{* * *}$ \\
\hline White/Non-White & $.068(.136)$ \\
\hline Term Limits & $.222(.167)$ \\
\hline Comparative District Size & $-.286(.821)$ \\
\hline \multicolumn{2}{|l|}{$\begin{array}{l}\mathrm{N}=693 \\
\text { Wald Chi } 2=58.85 \\
\text { Prob }>\text { Chi } 2=.00 \\
\text { Adj. } \mathrm{R}^{2}=.037 \\
{ }^{*} \mathrm{p}<.10 ;{ }^{* *} \mathrm{p}<.05 ;{ }^{* * *} \mathrm{p}<.01 \\
\text { Standard Error in Parentheses }\end{array}$} \\
\hline \multicolumn{2}{|c|}{$\begin{array}{l}\text { *Additional models were run investigating the Southern variable as a proxy for } \\
\text { Elazar's political culture classifications (1966). When included in the model, } \\
\text { Southern remained statistically significant, while the culture variables failed to } \\
\text { achieve statistical significance. An additional model was run that controlled for the } \\
\text { non-Southern traditionalistic states in Elazar's classification, and in this model } \\
\text { Southern remained statistically significant while the new variable failed to achieve } \\
\text { statistical significance. We believe this further indicates that being a Southerner, } \\
\text { rather than a traditionalistic political culture, is what is driving these results. }\end{array}$} \\
\hline
\end{tabular}


When all variables are set at the mean, Southern legislators have a .64 probability of indicating that they are either considering or definitely planning a run for higher office, as opposed to non-Southern legislators, who have only a .37 probability of exhibiting the same level of ambition. This difference between Southern and nonSouthern legislators is substantively large, comparable to the difference in ambition between legislators in states with high and low levels of gubernatorial power (.56 to .29 probability) and legislators who are in the lowest and highest category of tenure (.52 to .33 probability). The difference outpaces the difference in ambition found between male and female legislators (.54 to .45 probability).

Having established the level of ambition among Southern legislators, we now turn to what tangible difference(s) that translates to with regard to time spent campaigning and legislating. The model in the first column in Table 3 tests whether Southern legislators will be significantly more likely to engage in strictly campaign activities than non-Southern legislators. The model in the second column tests whether Southern legislators will be significantly less likely to engage in strictly legislative activities than non-Southern legislators. Because the dependent variable ranges from zero to two an ordered logit was utilized for this analysis. 
Table 3: Time Spent Participating in Campaign and Legislative Activities by Legislative Characteristics

\begin{tabular}{|c|c|c|}
\hline & Campaign & Legislative \\
\hline Southern & $.553(.235)^{* * *}$ & $-.157(.237)$ \\
\hline Leadership & $.943(.473)^{* *}$ & $.825(.510)^{*}$ \\
\hline Professionalization & $4.109(.993)^{* * *}$ & $2.625(1.009)^{* *}$ \\
\hline Gubernatorial Power & $.356(.205)^{*}$ & $-.726(.218)^{* * *}$ \\
\hline Democrat/Republican & $.151(.155)$ & $.049(.163)$ \\
\hline Tenure & $.069(.073)$ & $.223(.076)^{* * *}$ \\
\hline Female & $-.074(.164)$ & $.543(.176)^{* * *}$ \\
\hline White/Non-White & $.166(.136)$ & $.162(.143)$ \\
\hline Term Limits & $.068(.165)$ & $.148(.167)$ \\
\hline District Size & $3.110(1.293)^{* *}$ & $-1.457(1.025)$ \\
\hline \multirow[t]{2}{*}{ Ambition } & $.221(.092)^{* *}$ & $.017(.095)$ \\
\hline & $\begin{array}{l}\mathrm{N}=676 \\
\mathrm{LR} \mathrm{Chi}^{2}(11)=105.35 \\
\text { Prob }>\mathrm{Chi}^{2}=.0000 \\
\text { Pseudo } \mathrm{R}^{2}=.0748 \\
{ }^{*} \mathrm{p}<.10 ;{ }^{* *} \mathrm{p}<.05 ;{ }^{* *} \mathrm{p}<.01 \\
\text { Standard Errors in Parentheses }\end{array}$ & $\begin{array}{l}\mathrm{N}=661 \\
\mathrm{LR} \mathrm{Chi}^{2}(11)=34.44 \\
\text { Prob }>\mathrm{Chi}^{2}=.0003 \\
\text { Pseudo } \mathrm{R}^{2}=.0313 \\
{ }^{*} \mathrm{p}<.10 ;{ }^{* *} \mathrm{p}<.05 ;{ }^{* * *} \mathrm{p}<.01 \\
\text { Standard Errors in Parentheses }\end{array}$ \\
\hline
\end{tabular}

The findings presented in Table 3 provide support for our expectation. In the first column, the positive coefficient for the Southern variable confirms our suspicion that Southern legislators are more likely to spend time engaging in campaign activities than non-Southern legislators. Likewise, ambition behaves in the manner expected, as legislators who indicate a desire to seek higher office are more likely to engage in campaign activities than those who are less ambitious. The fact that both the Southern and ambition variables are significant confirms that each independently influences legislator preferences regarding their desire to engage in campaign activities. The positive, significant coefficient for the leadership variable indicates that legislators who hold a leadership position in their legislature are more likely to engage in campaign activities. From an institutional perspective, legislators in states with more professional legislatures, and legislators in states with a higher level of gubernatorial power, are more likely to engage in campaign activities. Legislators in larger districts also spend more time engaging in campaign activities, likely because they have a broader audience to reach than those in smaller districts. Party identification, sex, race, term limits, and length of legislative tenure all failed to achieve statistical significance in the model.

As a reminder, the model presented in the second column examines time spent engaging in legislative activities. In this instance the Southern variable in this model fails to reach statistical significance. This indicates that there is no significant difference between Southern and non-Southern legislators with regards to their propensity to engage in legislative behavior. The positive coefficient for leadership position indicates that those who hold leadership positions are more likely to spend more time engaging in the legislative activities listed than 
those who do not hold these positions. The positive coefficients for tenure and sex indicate that legislators who have served for longer periods of time as well as female legislators are more likely to engage in legislative activities than legislators who have served for a shorter period of time and male legislators, respectively. The negative coefficient for gubernatorial power indicates that legislators in states with stronger governors are less likely to engage in legislative activities than legislators in states with weaker governors. Legislators in states with more professional legislatures are also more likely to spend time engaging in legislative activities, likely because they have resources at their disposal that makes the task easier. District size, term limits, party identification, ambition, and race of the legislator all failed to achieve statistical significance in the model.

Predicted probabilities were calculated to illustrate the effect that being a Southerner has on how much time legislators spend engaging in campaign activities, with all other variables set at their mean value.

Table 4: Predicted Probabilities of Time Spent on Campaign Activities by Region

\begin{tabular}{|l|l|l|}
\hline & Southern & Non-Southern \\
\hline Little & .13 & .20 \\
\hline Moderate & .49 & .54 \\
\hline Great Deal & .38 & .26 \\
\hline
\end{tabular}

As Table 4 illustrates, Southern legislators have only a .13 probability of spending a little amount of time engaging in campaign activities, compared to a .20 probability that nonSoutherners will only spend a little amount of time engaging in these activities. Southern legislators have a .49 probability of spending a moderate amount of time engaging in campaign activities, while non-Southerners have a .54 probability of spending a moderate amount of time engaging in these activities. In contrast, Southern legislators have a 38 probability of spending a great deal of time engaging in campaign activities, while non-Southern legislators only have a .26 probability of falling in this category.

The model in the first column of Table 5 tests whether Southern legislators will be significantly more likely to prefer to spend their time engaging in strictly campaign activities than non-Southern legislators. The model in the second column of Table Five tests whether Southern legislators will be significantly less likely to prefer to spend their time engaging in strictly legislative activities than non-Southern legislators. Because the dependent variable ranges from zero to two an ordered logit was utilized for this analysis. 
Table 5: Ideal Time Spent Participating in Campaign and Legislative by Legislative Characteristics

\begin{tabular}{|c|c|c|}
\hline & Campaign & Legislative \\
\hline Southern & $.602(.230)^{* *}$ & $-.770(.240)^{* * *}$ \\
\hline Leadership & $.802(.501)$ & $.061(.482)$ \\
\hline Professionalization & $3.961(1.005)^{* * *}$ & $2.442(.991)^{* *}$ \\
\hline Gubernatorial Power & $.227(.206)^{*}$ & $-.411(.213)^{* *}$ \\
\hline Democrat/Republican & $-.114(.157)$ & $-.288(.162)^{*}$ \\
\hline Tenure & $.001(.073)$ & $.103(.075)$ \\
\hline Female & $-.283(.167)^{*}$ & $.535(.173)^{* * *}$ \\
\hline White/Non-White & $.305(.151)^{* *}$ & $-.138(.143)$ \\
\hline Term Limits & $.163(.187)$ & $.036(.191)$ \\
\hline District Size & $.954(.979)$ & $-1.396(.965)$ \\
\hline \multirow[t]{2}{*}{ Ambition } & $.305(.073)^{* * *}$ & $.216(.095)^{* *}$ \\
\hline & $\begin{array}{l}\mathrm{N}=674 \\
\mathrm{LRCh}{ }^{2}(11)=71.88 \\
\text { Prob }>\mathrm{Chi}^{2}=.0000 \\
\text { Pseudo } \mathrm{R}^{2}=.0529 \\
{ }^{*} \mathrm{p}<.10 ;{ }^{* *} \mathrm{p}<.05 ;{ }^{* * *} \mathrm{p}<.01 \\
\text { Standard Errors in Parentheses }\end{array}$ & $\begin{array}{l}\mathrm{N}=673 \\
\mathrm{LRCh}{ }^{2}(11)=38.57 \\
\text { Prob }>\mathrm{Chi}^{2}=.0001 \\
\text { Pseudo } \mathrm{R}^{2}=.0345 \\
{ }^{*} \mathrm{p}<.10 ;{ }^{* *} \mathrm{p}<.05 ;{ }^{* * *} \mathrm{p}<.01 \\
\text { Standard Errors in Parentheses }\end{array}$ \\
\hline
\end{tabular}

The positive coefficient for the Southern variable confirms our suspicion that Southern legislators are more likely to want to spend more time engaging in campaign activities than nonSouthern legislators. Ambition behaves in the manner expected, as legislators who indicate a desire to seek higher office are more likely to want to spend more time engaging in campaign activities than those who are less ambitious. Again, the fact that both the Southern and ambition variables are significant confirms that each independently influences legislator preferences regarding their desire to want to spend more time engaging in campaign activities. From a demographic perspective, race and sex are statistically significant, indicating that male legislators and nonwhite legislators are more likely to want to spend more time engaging in campaign activities than female and white legislators, respectively. From an institutional perspective, legislators in states with more professional legislatures, and legislators in states with a higher level of gubernatorial power, are more likely to indicate a desire to spend more time engaging in campaign activities. Party identification, district size, term limits, leadership, and length of legislative tenure all failed to achieve statistical significance in the model.

As a reminder, the model presented in the second column examines the self-reported ideal amount of time legislators would like to spend engaging in legislative activities. The negative coefficient for the Southern variable indicates that Southern legislators would like to spend less time engaging in purely legislative activities than non-Southern legislators. The 
coefficient for ambition is positive and significant, indicating that more ambitious state legislators would ideally like to spend more time participating in legislative activities. Sex reaches statistical significance, indicating that female legislators are more likely to want to spend more time engaging in legislative activities than male legislators. Institutionally, legislators in states with more professional legislatures are more likely to want to spend time engaging in legislative activities, and conversely legislators in states with higher levels of gubernatorial power are less likely to want to spend time engaging in legislative activity. The coefficient for party identification is negative and significant, indicating that Democratic legislators are more likely to express a desire to spend more time engaging in legislative activities that Republican legislators. Leadership, race, term limits, and length of legislative tenure all failed to achieve statistical significance in the model.

Again predicted probabilities were calculated to illustrate the effect that being a Southerner, with all other variables set at their mean value, has on how much time legislators would ideally spend engaging in campaign and legislative activities.

Table 6: Predicted Probabilities of Ideal Amount of Time Spent on
Campaign and Legislative Activities by Region
\begin{tabular}{|l|l|l|}
\hline & Southern & Non-Southern \\
\hline Campaign Little & .08 & .14 \\
\hline Campaign Moderate & .40 & .49 \\
\hline Campaign Great Deal & .52 & .37 \\
\hline & & .03 \\
\hline Legislative Little & .07 & .50 \\
\hline Legislative Moderate & .65 & .47 \\
\hline Legislative Great Deal & .29 & \\
\hline
\end{tabular}

The first set of categories in Table 6 examines the ideal amount of time spent engaging in campaign activities. Southern legislators demonstrate a .08 probability of falling into the lowest category of ideal amount of time spent campaigning, as opposed to non-Southerners, who have a .14 probability of falling into this category. In contrast, Southern legislators demonstrate a .52 probability of indicating a preference to spend even more time campaigning, as opposed to the .37 probability to do the same demonstrated by non-Southern legislators.

A much different pattern emerges in the second set of categories regarding ideal amount of time spent engaging in legislative activity. Southern legislators would strongly prefer to spend only a moderate amount of time engaging in legislative work (.65 probability). Non-Southern legislators, however, appear to be significantly more motivated to engage in legislative work, as they demonstrated a .47 probability of preferring to spending a great deal of time engaging in legislative activity. 


\section{Discussion}

The motivation to seek higher office, and the extent to which that shapes the behavior of politicians, is one of the more complex phenomena in contemporary political science. This research has attempted to shed light on one important facet of this topic. The research finds that Southern legislators exhibit higher levels of political ambition than non-Southern legislators, which could impact their preferences regarding how they spend their time, and how they would like to spend their time, both on the campaign trail and in the legislature. The findings have largely supported this argument; the ambition of Southern legislators to seek higher office appears to influence their preferences on how they spend their time in office.

To review, Southern legislators are far more likely than non-Southern legislators to indicate a desire to seek higher office. Southern legislators demonstrated a .64 probability of progressive ambition, as opposed to only .37 probability of non-Southern legislators. This difference is substantively comparative with the differences found between legislators in states with high and low levels of gubernatorial power as well as legislators with longer and shorter amounts of tenure, and outpaces the difference in ambition found with regards to sex. What does this tell researchers about Southern identity? The finding that Southern legislators have higher levels of political ambition justifies grouping them as distinctively different from other state legislators based on common political motivations. While there is strong empirical evidence to establish that Southern legislators express higher levels of ambition than their counterparts, it is much more difficult to pinpoint the source of the difference. The finding fits well with the explanation that Southern legislators choose common political strategies for electoral success. The commonality follows from a unique social and political history that created a common political culture amongst Southern voters. In an attempt to maintain support from these voters, Southern legislators respond to common political motivations that shape their strategic decisions. Southern politics has historically been dominated by representatives of the social and political elite (Woodard 2006). Because political leadership has generally been left to a smaller group of elites, this might offer some insight into why Southern legislators express higher levels of ambition than their non-Southern counterparts. They believe that seeking office and becoming a member of this elite will translate into longevity and influence. It is also likely that one-party dominance across most Southern states promotes the emergence of legislators that are characteristically different from other regions. Strategic politicians respond to their electoral context and environment. Differences in electoral environments will lead to different strategic considerations that will ultimately produce a qualitatively different group of legislators.

It is less clear how Southern identity leads to favoring political campaign activity over legislative activity. This is especially puzzling given that Southern legislators operate in districts that are, on average, amongst the safest in the nation from an electoral competitiveness standpoint (Klarner, 2015). As stated previously, a possible explanation of this starts with members of Congress's focusing on reelection (Mayhew, 1974). Research cited at the beginning of the paper suggests that Southern voters are more ideologically conservative, religious, and supportive of the status quo, than voters in other parts of the country. In trying to satisfy these constituents, Southern legislators may adopt common strategic behaviors in office. Fenno finds that many of his subjects who represent rural districts pursue a style where they emphasize face- 
to-face interactions with their rural constituents over other types of interactions (Fenno, 2003. 154-157). Although Southern identity refers to both urban and rural districts the common set of values across southern constituencies align with this rural perspective. This suggests that the pursuit of face to face interactions would appeal to southern voters. It is not a stretch to argue that political campaign activities are a more formal version of these face-to-face interactions. Southern identity then supports political campaign activities as a successful strategy for Southern legislators to pursue to gain political support over the less desirable legislative activities.

This is an interesting area of Southern politics that certainly merits further research. One logical extension of this research is to further explore the notion of distinctiveness among Southern legislators. Specifically, future research should explore the psychological characteristics of Southern legislators. One potential avenue is to apply the Five Factor Model to determine whether there are any personality differences between Southern and non-Southern legislators which may be driving this higher level of ambition. This work might also provide connections between political behaviors and Southern distinctiveness. Another avenue to pursue would be to apply this same approach to determine if there are any differences in personality characteristics which influence the differences in time preferences between Southern and nonSouthern legislators. Finally, future research should explore the various career paths taken by Southerners to elected office in order to determine if this level of ambition results in any significant distinctions in the electoral routes taken by Southern and non-Southern legislators. 


\section{Bibliography}

Barber, James David. 1965. The Lawmakers: Recruitment and Adaption to Legislative Life. New Haven, CT: Yale University Press.

Beyle, Thad. 2007. "Gubernatorial Power: The Institutional Power Ratings for the 50 Governors of the United States.” http://www.unc.edu/ beyle/gubnewpwr.html (February 18, 2011).

Black, Earl, and Merle Black. 1992. The Vital South: How Presidents Are Elected. Cambridge, MA: Harvard University Press.

Bullock III, Charles S. 2009. "Introduction: Southern Politics in the Twenty-First Century." In Charles S. Bullock III, and Mark J. Rozell, editors. The New Politics of

the Old South: An Introduction to Southern Politics, 4th edition. Lanham, MD:

Rowman and Littlefield, 1-25.

Bullock III, Charles S. and Mark J. Rozell. 2009. The New Politics of the Old South:

An Introduction to Southern Politics, 4th edition. Lanham, MD: Rowman and Littlefield.

Burden, Barry C, and David C Kimball. 2002. Why Americans Split Their Tickets: Campaigns, Competition, and Divided Government. Ann Arbor: University of Michigan Press

Cash, W.J. 1941. The Mind of the South. New York, NY: Knopf.

Cowden, Jonathan. 2001. "Southernization of the Nation and the Nationalization of the South: Racial Conservatism, Social Welfare, and White Partisans in the United States, 1956-1992." British Journal of Political Science 31: 277-301.

Elazar, Daniel. 1966. American Federalism: A View from the States. New York: Thomas Y. Crowell.

Erikson, Robert S., John P. McIver, and Gerald C. Wright. 1987. "State Political Culture and Public Opinion.” The American Political Science Review 81: 797-814

Fenno, Richard F. 2003. Home Style: House Members in Their Districts. Longman's Classics in Political Science. Longman, New York.

Fitzpatrick, Jody F. and Rodney E. Hero. 1988. "Political Culture and Political Characteristics of the American States: A Consideration of Some Old and New Questions." Western Political Quarterly 41: 145-153.

Gaddie, Ronald K. 2003. Born to Run: Origins of the Political Career. Lanham, MD: Rowman and Littlefield. 
Gibson, James L., Cornelius P. Cotter, John F. Bibby and Robert J. Huckshorn. 1983. "Assessing Party Organizational Strength." American Journal of Political Science 27: 193-222.

Glenn, Norval and J.L. Simmons. 1967. "Are Regional Cultural Differences Diminishing?” Public Opinion Quarterly 31: 176-93.

Griffin, Larry. 2006. “The American South and the Self." Southern Cultures 12: 6-28.

Hamm, Keith E., and Robert Harmel. 1993. "Legislative Party Development and the Speaker System: The Case of the Texas House." Journal of Politics 55: 140-51.

Harmel, Robert, and Keith E. Hamm. 1986. "Development of a Party Role in a No-Party Legislature." Western Political Quarterly 39: 79-92.

Hero, Rodney E. and Catherine J. Tolbert. 1996. "A Racial/Ethnic Diversity Interpretation of Politics and Policy in the States of the U.S." American Journal of Political Science 40: 851-71.

Hillygus, D. Sunshine and Todd Shields. 2008. "Polls and Elections: Southern Discomfort? Regional Differences in Voter Decision Making inthe 2000 Presidential Election.” Presidential Studies Quarterly 38: 506-520.

Holbrook, Thomas M., and Emily Van Dunk. 1993. "Electoral Competition in the American States." American Political Science Review 87: 955-62.

Hurlbert, Jeanne. 1989. “The Southern Region: A Test of the Hypothesis of Cultural Distinctiveness.” The Sociological Quarterly 30: 245-66.

Johnson, Charles A. 1976. "Political Cultures in American States: Elazar's Formulation Examined," American Journal of Political Science 20: 491-509.

Key, V. O. 1949. Southern Politics: In State and Nation. New York: Knopf.

King, James D. 2000. "Changes in Professionalism in U.S. State Legislatures." Legislative Studies Quarterly 25:327-43.

King, James D. 2004. "Political Culture, Registration Laws, and Voter Turnout among the American States." Publius 24:115-127.

Klarner, Carl. 2015. "Democracy in Decline: The Collapse of the "Close Race" in State Legislatures.” Ballotpedia.org.

Kuklinski, James H., Michael D. Cobb, and Martin Gitens. 1997. "Racial Attitudes and the 'New South." Journal of Politics 59:323-349. 
Maestas, Cherie, Sarah Fulton, Sandy Maisel, and Walter Stone. 2006. "When to Risk It: Institutions, Ambitions, and the Decision to Run for the U.S. House." American Political Science Review 100 No. 2: 195-208.

Mayhew, David R. 1974. Congress: The Electoral Connection. Yale University Press. New Haven, Ct.

Morgan, David R. and Sheilah S. Watson. 1981. "Political Culture, Political System Characteristics, and Public Policies among the American States" Publius 21: 31-48.

Nardulli. 1990. "Political subcultures in the American states: An empirical examination of Elazar's formulation." American Politics Quarterly 18: 287-315.

Putnam, Robert. 1993. Making Democracy Work: Civic Traditions in Modern Italy. Princeton:Princeton University Press.

Reed, John Shelton. 1982. One South: An Ethnic Approach to Regional Culture. Baton Rouge: LSU Press.

Rice, Tom, William McLean, and Amy Larson. 2002. "Southern Distinctiveness Over Time: 1972-2000.” American Review of Politics 23: 193-220.

Schlesinger, Joseph. 1966. Ambition in Politics: Political Careers in the United States. Chicago: Rand McNally.

Shafer, Byron E., and Richard G. Johnston. 2001. "The Transformation of Southern Politics Revisited: The House of Representatives as a Window." British Journal of Political Science 31: 601-25.

Soule, John W. 1969. "Future Political Ambitions and the Behavior of Incumbent State Legislators." Midwest Journal of Politics. 13: 439-54.

Squire, Peverill. 1992. "Legislative Professionalization and Membership Diversity in State Legislatures.” Legislative Studies Quarterly 17: 69-79.

Squire, Peverill. 2000. "Uncontested Seats in State Legislative Elections.” Legislative Studies Quarterly 25: 131-46.

Squire, Peverill. 2007. "Measuring State Legislative Professionalism: The Squire Index Revisited." State Politics \& Policy Quarterly 7: 211-22.

Turner, Joel, Scott Lasley and Jeffrey P. Kash. 2017. “The Big Five and Southern Legislative Distinctiveness." Forthcoming in Social Science Quarterly. 
Valentino, Nicholas A. and David O. Sears. 2005. "Old Times There Are Not Forgotten: Race and Partisan Realignment in the Contemporary South." American Journal of Political Science 49: 672-688.

Wattenberg, Martin. 2002. Where Have All the Voters Gone? Cambridge, MA: Harvard University Press.

Wright, Gerald C., Robert S. Erikson, and John P. McIver. 1985. "Measuring State Partisanship and Ideology with Survey Data.” Journal of Politics 47:469-89.

Woodard, J. David. 2006. The New Southern Politics. Boulder, CO: Lynne Rienner Publishers. 